\title{
NUCLEAR ENERGY: AN ETHICAL USE OF RESOURCES
}

\author{
NaHrul Khair Alang MD. Rashid \\ Department of Mechatronics Engineering, \\ Kulliyyah of Engineering, \\ International Islamic University Malaysia, \\ Jalan Gombak, 53100, Kuala Lumpur, Malaysia. \\ nahrul@iium.edu.my
}

\begin{abstract}
Energy is the lifeblood of development, but its amount is finite. It can neither be created nor destroyed; but it can be converted from one form to another. The conversion changes the state of the resources and the change generally is not reversible. Nuclear energy steadily contributes about 16 percent to global total electricity demand. Its application for electricity production is expected to increase due to dwindling natural resources, concern for greenhouse gaseous emission, and the limited capability of renewable energy and biofuels to be major energy resources. Nuclear energy, however, is plagued with ever presence public perception issues, some are real some are due to misperceptions. The trio of accidents: Three Mile Island, Chernobyl, and most recently, Fukushima, however has slightly dampened the prospect. Nuclear energy makes use of uranium, an element that has no peaceful applications other than to be used in nuclear power reactors to generate heat or neutrons, produce steam, and drive turbo-generators for electricity production. Other resources, such as oil, coal, and gas have multiplicity of uses that cannot be substituted by uranium. On that premise, this paper argues that the use of nuclear energy is an ethical choice. This choice overrides considerations, such as waste, complexity, and safety that are often projected as reasons for avoiding it altogether. Those considerations are of scientific and engineering dimensions that mankind has to wrestle and overcome as the khalifah. In so doing, proper education and ethical use of knowledge become imperative.
\end{abstract}

ABSTRAK: Tenaga adalah nadi pembangunan, tetapi jumlahnya terbatas. Ia tidak boleh dicipta atau dimusnahkan; tetapi ia boleh ditukar dari satu bentuk ke bentuk lain. Pertukaran bentuk ini mengubah keadaan sumber tenaga dan perubahan tersebut tidak boleh ditukarbalik. Tenaga nuklear menyumbang kira-kira enam belas peratus kepada jumlah permintaan elektrik global. Keperluan tenaga elektrik dijangka meningkat kerana pengurangan sumber asli, kebimbangan atas pelepasan gas rumah hijau, dan keupayaan biofuel dan tenaga boleh diperbaharui untuk menjadi sumber tenaga utama. Namun begitu, tenaga nuklear sentiasa dibelenggu oleh isu-isu persepsi umum, sebahagiannya benar dan sebahagian lagi disebabkan oleh salah anggap. Ketiga-tiga kemalangan nuklear: Three Mile Island, Chernobyl, dan baharu-baharu ini, Fukushima, bagaimanapun menjejaskan sedikit prospek berkenaan. Tenaga nuklear menggunakan uranium, suatu unsur yang tidak mempunyai sebarang kegunaan aman selain daripada digunakan dalam reaktor nuklear untuk menjana neutron atau haba, menghasilkan wap, dan memacu turbo-generator yang mengeluarkan elektrik. Sumber-sumber lain seperti minyak, arang batu dan gas mempunyai pelbagai kegunaan yang tidak boleh digantikan oleh uranium. Atas hujjah itu, rencana ini mengutarakan bahawa penggunaan tenaga nuklear adalah pilihan yang beretika. Pilihan ini mengatasi pertimbangan-pertimbangan seperti sisa, kerumitan teknologi, dan keselamatan yang sering ditonjolkan sebagai alasan untuk mengelakkan sama sekali kegunaan tenaga nuklear. Pertimbangan- 
pertimbangan tersebut adalah dalam dimensi saintifik dan kejuruteraan yang manusia, sebagai khalifah, perlu tangani dan atasi. Dalam berbuat demikian, pendidikan yang sempurna dan penggunaan pengetahuan yang beretika menjadi penting.

KEYWORDS: nuclear energy; greenhouse gas; renewable energy; ethical energy use; nuclear fuel; uranium; nuclear reactor

\section{INTRODUCTION}

Energy is the lifeblood of development. When fire was discovered and its uses were mastered and expanded, mankind has been able to progress by the leaps and bound. It is used both as heat as well as light sources. The use of energy, today, has become one of the yardstick for the measurement of the progress of a country. The International Energy Agency, in its recent report devised a means for linking energy usage and state of development in an index called Energy Development Index, which is based on per capita commercial and residential energy consumptions, share of modern fuel in total energy use in residential sector, and share of population with access to electricity[1]. It is clear that countries that are more developed has higher energy development index than those that are less developed.

Energy, however, is finite in amount. It can neither be created nor destroyed. It can be converted from one form to another that suits its intended application. The conversion changes the state of the resources and the conversion is generally not reversible in a short period of time. In this paper, we will be limiting the scope of discussion to only energy in the form of electricity. This is because it is the most used and transportable form of energy, and the first product of nuclear energy in this sense is electricity generation.

This paper presents the types of energy resources used for electricity generation in Section 2. This is followed by a comparison between the sources in Section 3 to lay the basis for subsequent discussions on ethical use in Section 4 that lead to a conclusion in Section 5 .

\section{ENERGY SOURCES}

\subsection{Fossil Fuels}

Up to now we have relied and still are relying largely on fossil fuels: coal, oil, and gas to produce electricity. These resources are used to produce heat that generate steam to drive turbo-generators that generate electricity. These resources are depleting and gradually become more costly to extract and process. Coupled to that is the unsettling political situation in most of the resource rich countries that affect supplies, hence driving the energy cost even higher. Furthermore, the effect of large scale usage of coal to the environment has raised a lot of concerns. Acid rain and greenhouse gaseous emission are closely attributed to the burning of coal for electricity production.

In fossil fueled power stations, the fuel must be fed continuously. Hence adequate feedstock must be maintained to ensure continuity of supplies for a specific period of time should supply disruption occurs.

Oil, however, is gradually being phased out from electricity generation purposes. The transportation sector is the major user of oil. With electrification of mass transport and better public transportation services dependency on oil for transportation could be reduced. This can increase the demand for electricity. 


\subsection{Renewable Energy}

Usage does not deplete the resources. This is the premise that makes RE attractive. Hydroelectric is one of the early means for electricity generation in this category. Other sources include solar, wind, wave, tidal, ocean thermal energy conversion and geothermal resources.

RE has some major limitations. These include generation, distribution, and storage. Solar energy is available only for a limited time of the day unless a more efficient and economical means for energy storage is available. This limitation makes them unsuitable for bulk power or base load applications.

\subsection{Replishnable Energy}

Biomass and biofuels tend to be lumped in the same category as RE. The author, however, is of the view that they belong to a new category that can be called 'replenishable.' This is if we take RE to mean usage does not diminish supply, and thus external efforts are not necessary to replenish the supply. We merely need to harvest the source. Biomass and biofuels, however, need replenishment. Plants must be replanted after they have been harvested for use.

At issue on biomass and biofuels, such as the use of corn, palm oil, and jathropha for instance, is related to the competing use of resources for the production of plants. With scarce land resources choice must be made between planting for food and planting for fuel. The choice of agriculture for fuel can drive food price up. To have energy security we should not compromise on food security. Both, RE and replenishable energy have yet to make impact in the total energy equation.

\subsection{Nuclear Energy}

Another form of energy source, generally termed as 'alternative' energy, is the use of nuclear fission process. Nuclear power reactors are considered as thermal power stations because apart from the use of nuclear reactions to generate heat, the rest of the plant operate in the same manner as other thermal power stations: steam is generated to drive turbogenerators that in turn generate electricity.

About $16 \%$ of global electricity production is generated using this means. The International Atomic Energy Agency (IAEA) reported that as of January 2010, there are 437 nuclear power reactors in operation with total capacity of 370 Gwe and fifty-five are under constructions [2].

France, has the highest percentage of nuclear electricity at $80 \%$. The largest number of nuclear reactors, however, is still in the United States of America. Other countries in the Asian region is fast catching up, commensurate with the rapid pace of growth in that region. China, for instance is on a fast track to introduce about $30 \%$ nuclear electricity by 2020. This translates into the connection to grid of one reactor every year until 2020. It however has reviewed this position in view of the Fukushima incident. Vietnam is reported to also be on the verge of introducing nuclear in her energy mix. South Korea began her fast development to acquire national capability in nuclear power technology about three decades ago. Today, South Korea can be regarded as one of supplier countries, and has won the contract to develop nuclear energy in the UAE.

\section{COMPARISONS OF RESOURCES}

\subsection{Means of Electriicity Generation}


In order to drive the point on resource utilization, the focus will be on the level of abundance of the fuel supplies, their other competing uses, and comparison of other selected factors. Since the sources of renewable energy are ever presence, or impossible to be created by men, unlike 'replenishable' resources, they are excluded from our discussion.

All energy sources are different, and they satisfy different types of loads. As alluded to above, however, nuclear and fossil fuels are similar in the sense that they are thermal power plants. In order to continuously generate electricity, heat must continuously be supplied.

\subsection{Fuel Supplies}

Coal accounts for about $41 \%$ of global electricity production. With current rate of consumption, the World Coal Association estimates that coal reserve will last for about 120 years. It also gives estimate for oil and gas at 46 and 63 years at current consumption and production level [3]. Thus, the use of coal for electricity generation is not expected to be abandoned soon.

The burning of coal however creates environmental problems such as greenhouse gaseous emissions and acid rain. It is estimated that coal burning for electricity production releases more than 8 billion tonnes of carbon dioxide annually. New technology could make coal cleaner, but it may also make it expensive that other alternatives such as nuclear becoming more attractive. The use of oil for electricity generation is being phased out.

The supply of uranium comes from two main sources: secondary and primary supplies. The secondary supplies includes those from the stockpiled used fuel, uranium from decommissioned nuclear arms following the end of the Cold War, reprocessed uranium, mixed oxide fuel, highly enriched uranium fuel, reprocessed fuel, and reenrichment of reprocessed fuel. The primary supplies are those newly mined and processed uranium. The International Atomic Energy Agency (IAEA) estimated that until the year 2050, the secondary supply will contribute up to $11 \%$ of the cumulative demand for uranium [4].

The trend of uranium production follows closely the demand from two of its main uses (Fig. 1). The decline after around 1960 and peaks in 1980 and 1988 correspond to the decrease of its military use and increase in demand for nuclear reactors, respectively [5].

At the current rate of consumption, the Nuclear Energy Agency estimated that the global uranium reserves would last for many centuries [6]. It is estimated that 1 tonnes of uranium can produce 40 million $\mathrm{KWhr}$ of electricity, which is equivalent to burning 16,000 tonnes coal or 80,000 barrels of oil.

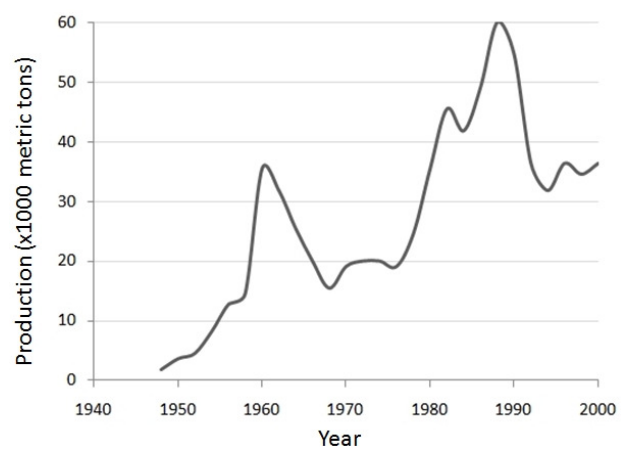

Fig. 1: World uranium production, 1948-2000. 


\subsection{Other Uses of Energy Resources}

Oil is largely used for transportation (land, air, sea). In addition to transportation it is also used to produce almost 500 items including many everyday products such as detergents, fertilizers, varnishes, paints, thinners, and industrial resins. The distillates are used for making electrical insulators, cosmetics, water repellant coatings, medicinal tablets, and sealants.

The only known peaceful uses of uranium is for the production of electricity. In its current means of generating electricity it can never be used to power vehicles, except submarines.

On that premise this paper argues that the use of nuclear energy is therefore an ethical choice. We should as far as possible used it so as to minimize other resources that have multiplicity of uses. Considerations such as safety and waste, so often projected as the reasons for avoiding it, are scientific and engineering problems that we, as khalifah, have to master. The next level is ethical use of nuclear energy itself. Technical as well as administrative procedures need to be in place for it to be used in ethical way.

\section{ETHICAL ISSUES OF NUCLEAR ENERGY}

\subsection{Nuclear Reactor Safety}

In general, it is unethical to adopt any technology that brings more harm than good. Nuclear energy is viewed in that light by some quarters. The recent incident at Fukushima nuclear power plants seems to strengthened that view. Looking in isolation that could be true to a certain extent; but looking from a different perspective, there are almost 50 more nuclear power reactors in operation elsewhere in that country.

A nuclear power plant is built according to a design basis accident that provides reference for the reactor design. It is a hypothetical accident that produce chain of events with eventual grave consequences such as core meltdown and release of fission products to the environment. In addition, the concept of multiple barrier is applied to stop fission products from being released to the environment. For fission products to escape it has to overcome several barriers including the fuel cladding, the reactor pressure vessel, and the containment building.

Despite being over 40 years old, indicating a technology that was designed at least of the same age, the Fukushima nuclear power plants responded positively to earthquake. All reactors shut down; pumps were operating to remove the residual heat to cool the reactor. However, this process was stopped when the offsite diesel generator that powers the pumps was taken by the tsunami. That the reactor core remained intact is a testimony to the design. The inability of the offsite power supply to withstand the tsunami, beyond the design level, is a weak link that points out to a need for future designs to accord higher level of safety to the auxiliary and support systems.

\subsection{Radiation Exposure}

Radiation is part of the environment, but they exist at a background level that is so low to be of health concerns. In fact, it could be the mutative agent that causes the generation of new species of plants and insects that were not discvered before. The effect is used in an accelerated scale in laboratories by inducing mutation in plant through exposure to radiation. This process, called radiation induced mutation breeding, produces new plant cultivars with better desired characteristics. 
In light of the Fukushima-Japan incidents in 2011, there are concerns on public exposure to rdaition especially when it is reported that the level is several folds of the background level. This is anotther issue that besieged the industry, but perhaps it is of their own making when the level is set too low. Some of the medical procedures that we have to take involving x-rays and other nuclear-related procedures are several times higher than the exposure limit sets for non-radiation workers. Table 1 for instance indicates the natural radioactivilty level in human body.

Table 1: Natural Radioactivity in the body.

\begin{tabular}{|l|l|l|l|}
\hline Nuclide & $\begin{array}{l}\text { Total } \\
\text { Mass }\end{array}$ & $\begin{array}{l}\text { Total } \\
\text { Activity }\end{array}$ & Daily Intake \\
\hline Uranium & $90 \mu \mathrm{g}$ & $1.1 \mathrm{~Bq}$ & $1.9 \mu \mathrm{g}$ \\
\hline Thorium & $30 \mu \mathrm{g}$ & $0.11 \mathrm{~Bq}$ & $3 \mu \mathrm{g}$ \\
\hline Potassium-40 & $17 \mu \mathrm{g}$ & $4.4 \mathrm{kBq}$ & $0.39 \mathrm{mg}$ \\
\hline Radium & $31 \mathrm{pg}$ & $1.1 \mathrm{~Bq}$ & $2.3 \mathrm{pg}$ \\
\hline Carbon-14 & $95 \mu \mathrm{g}$ & $15 \mathrm{kBq}$ & $1.8 \mu \mathrm{g}$ \\
\hline Tritium & $0.06 \mathrm{pg}$ & $23 \mathrm{~Bq}$ & $0.003 \mathrm{pg}$ \\
\hline Polonium & $0.2 \mathrm{pg}$ & $37 \mathrm{~Bq}$ & $\sim 0.6 \mu \mathrm{g}$ \\
\hline
\end{tabular}

\subsection{Proliferation and Technology Access}

The question of ethics are being discussed by many authors from many points of views. The concerns of states with nuclear weapons (NWS) could be different from the non-nuclear weapon states (NNWS). It is hypothesized that with the increasing use of nuclear energy there would be an increase of the possibility of proliferation of nuclaear weapons. Doyle [7] writes on the need for researching three main aspects of nuclear ethics: proliferation control, the threats of nuclear weapons, and relation between ethics and domestic political considerations.

The close linkage between nuclear energy for peaceful uses and military applications has been at the heart of most of the international safeguards and control regimes. Central to the link is uranium enrichment technology. With the exception of the CANDU reactors that use natural uranium, nuclear power reactors use uranium enriched to between 3-4\% in the isotopes of uranium-235. For non-peaceful purposes, the enrichment should be appraching $100 \%$. The abundance of that isotope in natural uranium is only $0.7 \%$. Proliferation is one of the ethical issues discussed internationally. The effectiveness of the Non-Proliferation Treaty to curb the spread of nuclear weapons among NNWS, access to technology that are useful for peaceful applications but also has ramifications in access to technologies that are excluded become contentious issues.

The non-peaceful uses of nuclear energy has been one of the reasons for continuing negative perception of the public on nuclear energy. Greater access to beneficial uses and encouragement on the development of uses in this direction could be an approach that could discourage others to do otherwise.

\subsection{Correct End Use}

Responsibe use could be the correct concept to use to separate the irresponsible use of nuclear technology from its beneficial uses. As every technology is a double-edge sword, 
IIUM Engineering Journal, Vol. 12, No. 5, 2011: Special Issue on Science and Ethics in Engineering

Md. Rashid

the concept should be the guiding principle on the use of nuclear energy. It would be hard to justify abandoning a technology on the basis that it can be used for other purposes. A technology is not made bad by the bad intention of the user.

\section{CONCLUSION}

The use of nuclear energy is an ethical choice in view of the multiplicity of uses of other resources. However, for it to be used properly it must be developed and utilized in the most responsible manner, complete with all necessary infrastructure to prevent untoward incidents and to mitigate the consequences of any accidents.

\section{REFERENCES}

[1] IEA, World Energy Outlook 2010.

[2] IAEA Annual Report 2009, IAEA, Vienna, 2010.

[3] World Coal Association website http:// www.worldcoal.org/resources/coal-statistics/ accessed on 14 April 2011.

[4] IAEA, Analysis of Uranium Supply to 2050, Vienna, 2001.

[5] W.I. Finch, Uranium-Fuel for Nuclear Energy 2002, USGS Bulletin 2179-A, 2003.

[6] R. Price and J.R.Blaise, Nuclear fuel resources: enough to last?, NEA News 2002, No.20.2, 2002.

[7] T.E.Doyle, "Reviving Nuclear Ethics: A Renewed Research Agenda for the Twenty-First Century," Ethics \& International Affairs, vol. 24.3, Fall 2010. 